\title{
ON DESIGNING THE AVERAGE LACTATION CURVE AT THE ASCENDING PHASE
}

\author{
AARNE MÄKELÄ \\ Department of Animal Husbandry, University of Helsinki
}

Received May 2, 1962

The lactation period can be divided in two parts, namely the ascending and the descending phases. The lactation curve illustrating the lactation period can likewise be divided in corresponding parts. The ascending phase begins at calving and ends at the peak production. The time between these points is the duration of the ascending phase.

By the term "peak production" is usually meant the highest daily yield, or the so-called absolute peak. Because its height and location in the lactation curve, however, depend much on external circumstances, the peak production is often calculated also as a mean of several days in highest region of the lactation curve. For instance Kajanoja and Silvennoinen-Larpes (2, p. 2) have chosen as the peak production the mean milk yield of four subsequent best days and as the peak point the second of these four days. The author proposes as the peak production the mean of three subsequent best days, with the requirement, however, that the production of the middlemost of these three days must be as high or higher than the production of the preceding or following day. The peak production is considered to be reached on the middlemost of these three days. The ascending phase thus ends on the day of peak production. In calculating the duration of the ascending phase, the day of calving has been considered as the 0-day. If several peak productions of the same height occur, the ascending phase is considered to terminate at the first peak. In well-fed herds the peak production indicates the maximal production capacity of a cow during a fixed lactation period. In this case the total amount of milk is considered. If, however, lactation curve is drawn on the basis of $4 \%$ fat corrected milk, the peak is reached earlier, according to Maymone and Malossini (3, p. 292).

The daily milk records of individual cows constitute the starting-point for the drawing of the average lactation curve. These records can be presented in the form 
of the table or a graphic figure. In the studies concerning the ascending phase of lactation known by the author, the average lactation curves have been usually designed in such a way that firstly the average productions of the individual cows are calculated on the first, the second, the third, etc. day and thereafter the series of the means are presented as a graphic figure. These means are also often presented in the form of a table. Instead of means of these individual days, Journet and JARRIGE (1) use the means of two subsequent days so that the yield of each day is included only in one mean. Kajanoja and Silvennoinen-Larpes (2) describe the average lactation curve during the ascending phase both by the method first mentioned as well as by designing a so-called average relative lactation curve. They firstly calculate for each cow how many per cent each day's milk yield is of peak production, and thereafter the means of these percentages are determined separately for each day. The results are presented both in the form of graphic figures and tables. The principle of the relative lactation curve has also been used by MAYMONE and MaLossini (3).

The lactation curves and corresponding tables designed by the above-described methods have, however, some drawbacks. For instance, it is not possible to determine with sufficient accuracy the height of the peak production, because the location of the peak is different in individual cows. It can be noted e.g. from the study of Kajanoja and Silvennoinen-Larpes that the highest point of the average relative lactation curve in cows older than heifer-cows is only about 93 per cent of the real average of the peak productions. Futher, the temporal location of the peak is poorly seen from them, and the average duration of the ascending phase is accordingly difficult to estimate.

In order to avoid the above-mentioned drawbacks, the author proposes that average lactation curves should be designed in such a way that both productions and times involved in reaching them are averages. These lactation curves can be called two-dimensional average lactation curves. In designing such curves, the peak production and the duration of the ascending phase are calculated separately for each cow. Thereafter, the productions at different times from calving are calculated as a mean of three subsequent days. These times are, for instance, 1/8, 1/4, 1/2, $3 / 4$, and $5 / 4$ of the duration of the ascending phase from calving. Following this, the mean productions of individual cows at the different times are calculated, and these averages are used to draw the two-dimensional average lactation curve during the ascending phase. In this curve the peak production is the mean of the peak productions of individual cows, and the time involved in reaching it is the mean of the durations of the ascending phases of the individual cows. According to the same principle, the two-dimensional average $\mathrm{r}$ e $\mathrm{l}$ a $\mathrm{t} \mathrm{i} \mathrm{v}$ e lactation curve at the ascending phase can also be designed.

In order to compare the peak productions chosen in different ways as well as the average lactation curves of the ascending phase designed in different ways, the daily milk yields of four cows belonging to the herd of the University Farm Viik have been chosen. The cows were older than heifer-cows, calved during the winter feeding period, and were healthy at the time of ascending phase. Two of these cows 
Table 1. The daily milk yields of the cows at the ascending phase, in kilograms.

\begin{tabular}{|c|c|c|c|c|c|c|c|c|c|c|c|}
\hline day & 0 & 1 & 2 & 3 & 4 & 5 & 6 & 7 & 8 & 9 & 10 \\
\hline Cow 1 & 0.0 & 8.4 & 12.0 & 12.9 & 14.7 & 16.3 & 17.7 & 19.7 & 20.3 & 20.4 & 20.9 \\
\hline , 2 & 3.1 & 15.1 & 17.5 & 17.4 & 19.9 & 21.7 & 22.9 & 22.3 & 22.0 & 21.4 & 21.2 \\
\hline , 3 & 0.0 & 9.0 & 13.8 & 14.5 & 16.9 & 18.1 & 18.9 & 20.4 & 20.1 & 21.7 & 21.2 \\
\hline 4 & 4.2 & 21.4 & 23.4 & 23.9 & 19.0 & 19.5 & 19.5 & 21.2 & 24.9 & 27.3 & 27.2 \\
\hline Average, kg & 1.8 & 13.5 & 16.7 & 17.2 & 17.6 & 18.9 & 19.8 & 20.9 & 21.8 & 22.7 & 22.6 \\
\hline & day & 11 & 12 & 13 & 14 & 15 & 16 & 17 & 18 & 19 & 20 \\
\hline Cow 1 & & 22.0 & 20.9 & $22.2^{*}$ & 20.9 & 21.6 & 21.1 & 21.7 & 21.6 & 21.8 & 22.1 \\
\hline , 2 & & 20.5 & 21.3 & 22.9 & 23.9 & 25.7 & 27.2 & $27.4^{\mathrm{k}}$ & 27.2 & 26.4 & 26.5 \\
\hline , 3 & & 21.1 & 20.6 & 21.5 & 17.5 & 17.2 & 20.4 & 21.8 & 21.1 & 20.3 & $22.2^{*}$ \\
\hline 4 & & 27.7 & 27.3 & 27.9 & 27.6 & 26.3 & 28.1 & 28.9 & 30.0 & 31.4 & 30.7 \\
\hline \multirow[t]{2}{*}{ Average, kg } & & 22.8 & 22.5 & 23.6 & 22.5 & 22.7 & 24.2 & 25.0 & 25.0 & 25.0 & 25.4 \\
\hline & day & 21 & 22 & 23 & 24 & 25 & 26 & 27 & 28 & 29 & 30 \\
\hline Cow 1 & & 21.2 & 21.9 & $21.9^{\mathrm{k}}$ & 21.9 & 21.7 & 20.7 & 21.7 & 20.2 & 18.5 & 20.9 \\
\hline - 2 & & 21.8 & 22.4 & 22.9 & 23.3 & 22.5 & 24.1 & 24.5 & 24.8 & 25.3 & 25.6 \\
\hline , 3 & & 19.3 & 21.4 & 20.1 & 20.9 & 21.9 & 18.6 & 20.5 & 19.2 & 20.3 & 21.8 \\
\hline , 4 & & 32.2 & 30.8 & 26.2 & 28.0 & 27.7 & 27.8 & 28.6 & 27.9 & 30.5 & 29.8 \\
\hline \multirow[t]{2}{*}{ Average, kg } & & 23.6 & 24.1 & 22.8 & 23.5 & 23.5 & 22.8 & 23.8 & 23.0 & 23.7 & 24.5 \\
\hline & day & 31 & 32 & 33 & 34 & 35 & 36 & 37 & 38 & 39 & 40 \\
\hline Cow 1 & & 20.8 & 20.9 & 19.8 & 19.8 & 19.7 & 19.5 & 19.4 & 19.5 & 19.3 & 19.5 \\
\hline , 2 & & 26.0 & 27.3 & 27.5 & 26.9 & 26.1 & 25.0 & 23.9 & 27.6 & 27.2 & $27.7^{*}$ \\
\hline - 3 & & 19.7 & 20.6 & 20.2 & 20.3 & 20.8 & 21.2 & 20.8 & 21.4 & 21.9 & $21.3^{\mathrm{k}}$ \\
\hline , 4 & & 29.4 & 30.6 & 31.9 & 34.1 & 33.5 & 34.4 & 34.3 & 30.8 & 34.8 & $34.0^{\mathrm{k}}$ \\
\hline \multirow[t]{2}{*}{ Average, kg } & & 24.0 & 24.9 & 24.9 & 25.3 & 25.0 & 25.0 & 24.6 & 24.8 & 25.8 & 25.6 \\
\hline & day & 41 & 42 & 43 & 44 & 45 & 46 & 47 & 48 & 49 & 50 \\
\hline Cow 1 & & 19.0 & 18.8 & 19.6 & 19.1 & 17.1 & 19.8 & 17.3 & 19.5 & 18.8 & 18.0 \\
\hline - 2 & & 26.4 & 24.7 & 24.8 & 25.0 & 25.7 & 25.8 & 25.4 & 24.2 & 24.3 & 24.2 \\
\hline - 3 & & 21.4 & 22.0 & 21.0 & 20.9 & 21.2 & 20.7 & 19.6 & 18.7 & 20.2 & 19.1 \\
\hline , 4 & & 34.1 & $35.5^{*}$ & 32.0 & 33.4 & 34.6 & 33.3 & 34.2 & 34.4 & 32.4 & 31.5 \\
\hline Average, kg & & 25.2 & 25.3 & 24.4 & 24.6 & 24.7 & 24.9 & 24.1 & 24.2 & 23.9 & 23.2 \\
\hline
\end{tabular}


has a relative short and two a relative long duration of the ascending phase. One cow in each subgroup had a relative low and the other cow a relative high peak production. The daily milk yields as well as the daily means of the yields of the cows can be seen in Table 1 .

In Table 1 the absolute peak is indicated by a star $\left({ }^{*}\right)$ and the peak estimated by the method of Kajanoja and Silvennoinen-Larpes by the letter k. In using the method of the author, the three days, the mean of which is the peak production, are printed by cursive. Of these days the peak is considered to be reached on the middlemost day. The peak productions chosen in different ways and the corresponding durations of the ascending phases can be seen from Table 2 . In calculating the duration of the ascending phase, the day of calving is considered as the 0 -day.

It can be seen from Table 2 that the absolute peak is distinctly higher than the peak productions found using both other methods. The peak productions found in

Table 2. The peak productions found in different ways and the corresponding durations of the ascending phases.

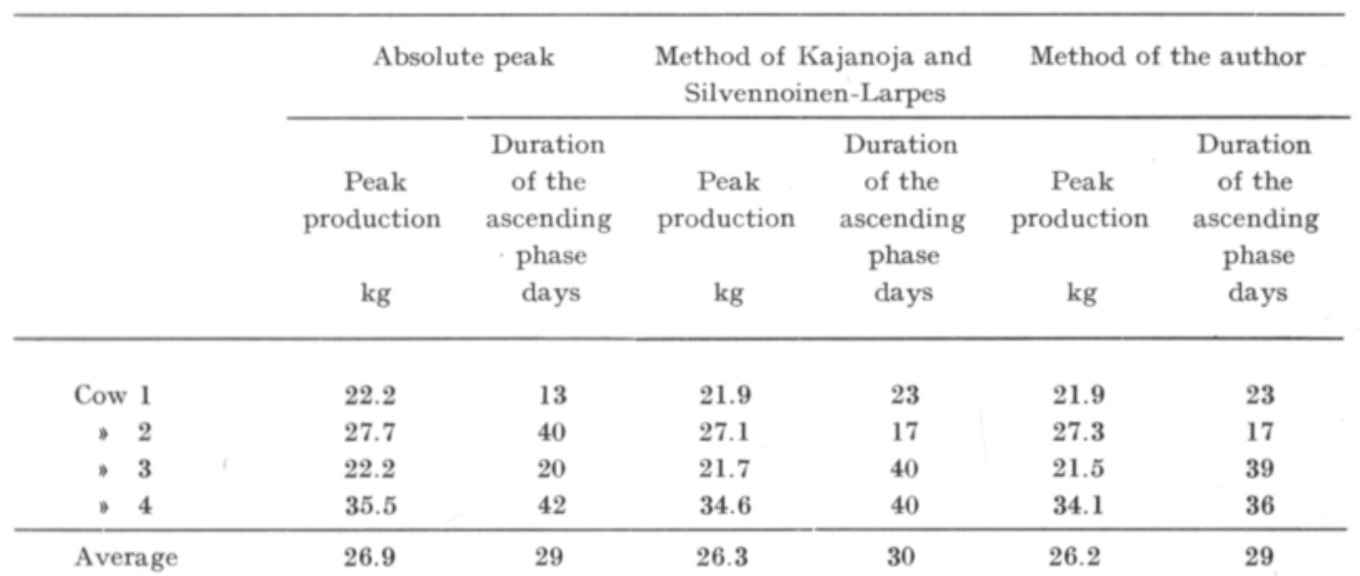

these latter ways are about of the same magnitude when compared with each other. The means of the durations of the ascending phases found in all these three ways are about the same. In individual cows, however, the duration of the ascending phase corresponding to the absolute peak may considerably differ from the durations of the ascending phases when the two other methods are used. When the absolute peak is used, the durations of the ascending phases, for instance in cows 2 and 3, differ considerably from each other in the opposite direction than when using the two other methods. These two latter methods give durations of about the same magnitude. In order to show the height and location of maximal production capacity in the lactation curve of the cow, it is preferable to choose the peak production as a mean of three subsequent best days. When the mean of three days is used, the variation of daily milk yield caused by certain irregularities, e.g. in the times between milkings and the withholding of the milk, are eliminated. In calculating the 
mean, the use of more than three days is unnecessary and even detrimental, because there is a tendency to get an unduly low peak production if the peak is the mean of too many daily milk yields.

Figure 1 shows the average lactation curve of the four above-mentioned cows designed in different ways. The lower curves present the rise in milk yield in kilograms and the higher curves the relative rise (in per cent of peak). The lower diagram

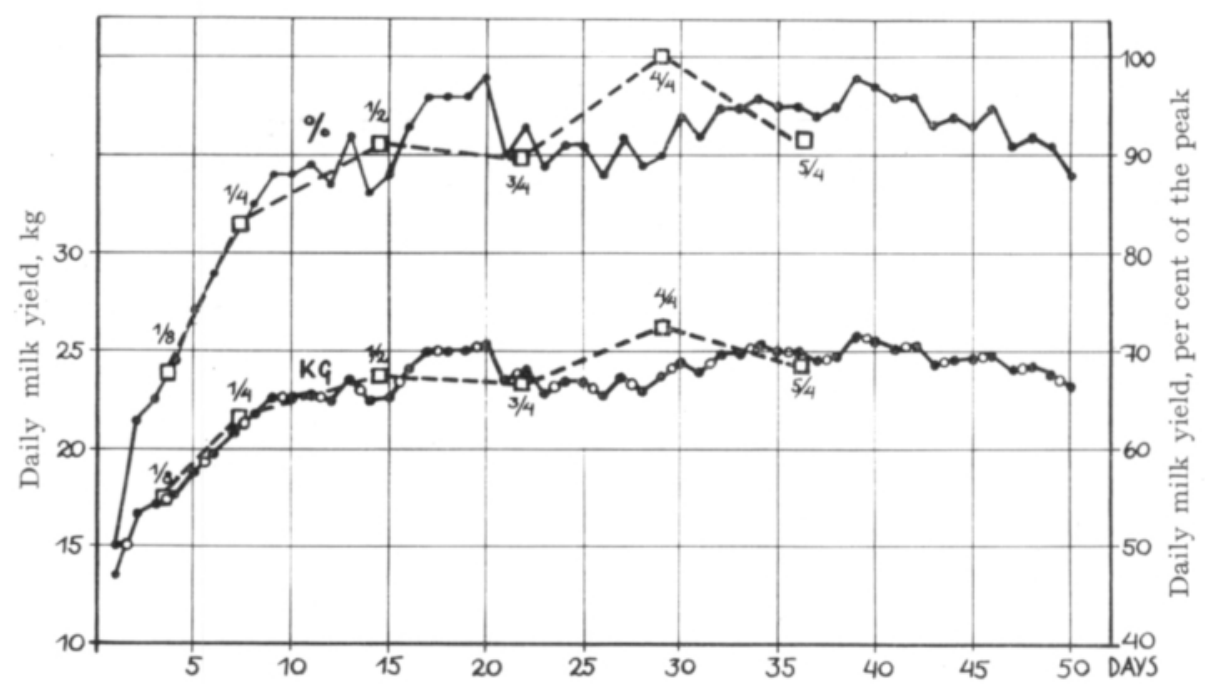

Fig. 1. Averzge lactation curve designed in different ways (Explanation in the text).

marked by black points has been drawn on the basis of the average values in Table 1 . The corresponding average relative lactation curve, also marked by black dots, has been designed according to the method of Kajanoja and Silvennoinen-Larpes. Concerning the lactation curve in kilograms and the peak as chosen according to the method of the author, the peak production is $25.4 \mathrm{~kg}$ and the time involved in reaching it is 39 days from calving. In addition there is a second peak of nearly the same height, $25.0 \mathrm{~kg}$, occurring 18 days after calving. The mean of the peak productions of the cows is $26.2 \mathrm{~kg}$ and the mean of the durations of the ascending phases 29 days. At this point the average lactation curve runs considerably lower. Thus on the basis of the curve, one cannot get a true picture of the height and location of the average peak. An error of the same kind of relatively the same magnitude is made when the average relative lactation curve described above is used.

The white circles in the above-mentioned kg-curve (Fig. 1) show the milk yields at different times as calculated according to the method of Journet and Jarrige. The curve drawn through these circles is more uniform than the kg-curve with black dots. 
The average lactation curves designed according to the method of the author are marked in Fig. 1 by squares. They have been drawn separately from the milk yields in kilograms and the relative milk yields. In order to draw this average kgcurve Table 3 was first compiled.

In Table 3 the milk yields of individual cows are averages of three days. From these days the middlemost day is $1 / 8,1 / 4,1 / 2,3 / 4,4 / 4$ or $5 / 4$ of the duration of the ascending phase. For instance, the duration of the ascending phase in cow 1 is 23 days. Of this $1 / 8$ is about 3 . The yield on the point $1 / 8$ is calculated as the mean of the second, the third and the fourth day, and consequently according to Table 1 $(12.0+12.9+14.7): 3=13.2 \mathrm{~kg}$. At each time the means of the individual cows have been calculated. The average times are found by multiplying the means of the durations of the ascending phases by the figures $1 / 8,1 / 4,1 / 2,3 / 4,4 / 4$, and $5 / 4$. For instance, at the time $1 / 8$ the average time from calving can be found by performing the computation $1 / 8 \cdot 29=3.6$ days. The lactation curve is drawn by using the means of both the productions and the times.

Table 3. Auxiliary table for drawing the lactation curve at the ascending phase according to the method of the author.

\begin{tabular}{cccccccc}
\hline & $\begin{array}{c}\text { Duration of } \\
\text { the ascending } \\
\text { phase } \\
\text { days }\end{array}$ & \multicolumn{6}{c}{$\begin{array}{c}\text { Production }(\mathrm{kg}) \text { on the point of a fixed } \\
\text { fraction of the duration of the ascending phase }\end{array}$} \\
& & $1 / 8$ & $1 / 4$ & $1 / 2$ & $3 / 4$ & $4 / 4$ & $5 / 4$ \\
\hline & 23 & 13.2 & 17.9 & 21.3 & 21.5 & 21.9 & 19.9 \\
Cow 1 & 17 & 16.7 & 19.7 & 21.9 & 22.7 & 27.3 & 23.6 \\
2 & 39 & 19.1 & 21.3 & 21.2 & 20.4 & 21.5 & 19.3 \\
3 & 36 & 20.8 & 26.5 & 30.1 & 28.1 & 34.1 & 33.8 \\
\hline 4 & 29 & 3.6 & 7.3 & 14.5 & 21.8 & 29 & 36.3
\end{tabular}

In order to draw average relative lactation curve by the aid of the figures in Table 3, the per cent of the milk yields (means of three days) relative to the peak production have been calculated separately for each cow. From these percentages, the means at each time are determined. The mean of the time points are the same as in the lactation curve in kilograms.

In these lactation curves the peak production is the mean of the peaks of individual cows, and the time involved in reaching it is the mean of the durations of the ascending phases of the individual cows. At this point the lactation curves run considerably above the curves reported earlier. On the other hand, the curves nearly join each other from calving until $3 / 4$ of the duration of the ascending phase as well as also $1 / 4$ of the duration of the ascending phase after the peak. It can also be mentioned that the method of the author involves daily milk weighings only until the peak has been passed by one fourth of the duration of the ascending phase. On the 
other hand, the other methods reported in this paper require that milk weighings must be continued until at least a considerable number of the cows with a relatively long duration of the ascending phase have reached their peak production.

\section{$S u m m$ ary}

Comparisons are made between different methods to find the peak production (maximum daily milk yield) and methods to design the average lactation curve at the ascending phase in dairy cows. It was noted that in order to determine the height and location of the maximal producing capacity of a cow in a known lactation period, it is preferable to choose the peak production as a mean of three subsequent best days. It was also noted that the usual methods for drawing the average lactation curves do not give a true picture of the height and location of the peak. The author suggests a method for determining the average lactation curve at the ascending phase by using the averages of both milk productions and times involved in reaching the peak and known fractions (e.g. 1/8, 1/4, 1/2,3/4, and 5/4) of it. In this lactation curve the peak production is the mean of the peaks of individual cows, and the time involved in reaching it is the mean of the durations of the ascending phases of the individual cows.

\section{REFERENCES}

(1) Journet, M. \& JARrige, R. 1960. Évolution de la sécrétion des matières grasses, des matières azotées et du lactose au cours du premier mois de lactation. Ann. Inst. Natl. Rech. Agron. Sér. D. Ann. Zoot. 9: 133-155.

(2) Kajanoja, P. \& Silvennoinen-Larpes, E.-L. 1959. Lehmän herumisnopeudesta ja siihen vaikuttavista tekijöistä. (Summary: On the speed of milk yield increase in the early stages of lactation in cows and on factors affecting it). Acta agr. fenn. 94: 1-14.

(3) Maymone, B. \& Malossini, F. 1959. The rising phase of the lactation curve in dairy cows. Z. Tierzücht. und Zücht. biol. 73: 276-294.

SELOSTUS:

KESKIMÄÄRÄISEN HERUMISKÄYRÄN PIIRTÄMISESTÄ

AARNe MÃKelä

Kotieläintieteen laitos, Helsingin yliopisto

Kirjoituksessa verrataan keskenään muutamia herumishuipun valitsemistapoja sekä keskimääräisen herumiskäyrän piirtämistä koskevia menetelmiä. Tällöin todettiin, että herumishuippu parhaiten valitaan kolmen peräkkäisen parhaan päivän keskiarvona, jotta-lehmän maksimaalisen tuotantokyvyn suuruus ja sijainti tiettynä lypsykautena voisivat lypsykäyrässä ilmetä. Eräistä käytännössä olevista keskimääräisen herumiskäyrän laatimista koskevista menetelmistä todettiin, että niitten avulla laaditusta herumiskäyrästä ei saada oikeata kuvaa keskimääräisestä herumishuipusta ja sen sijainnista. Kirjoittaja ehdottaa keskimääräisen herumiskäyrän piirtämistä siten, että sekä maitotuotokset ettă herumiskauden ja sen määrättyjen murto-osien (esim. 1/8, 1/4, 1/2, 3/4 ja 5/4) pituudet ovat keskiarvoja. Keskimääräistä herumiskäyrää kuvaavan murtoviivadiagramman korkein kohta on tällöin herumishuippu. Diagramman muut kohdat liittyvät läheisesti aikaisemmilla menetelmillä laadittuihin herumiskäyriin. 